\title{
ATRAÇÃO E INSERÇÃO PROFISSIONAL DE BOLSISTAS EGRESSOS DO PIBID TAUBATÉ
}

\author{
Rafael Marques Gobbo' \\ Neusa Banhara Ambrosetti ${ }^{2}$
}

Resumo: O objetivo do trabalho é analisar os efeitos do PIBID (Programa Institucional de Bolsa de Iniciação à Docência), desenvolvido a partir do ano de 2011 por uma universidade no Estado de São Paulo, para a formação e a continuidade profissional de estudantes de licenciatura, na perspectiva de bolsistas que participaram do programa. Na abordagem metodológica para a realização desse estudo foram utilizadas seis entrevistas reflexivas com bolsistas de diferentes licenciaturas, participantes do PIBID entre os anos de 2012 a 2014 nessa instituição. Os resultados indicam que as vivências e experiências proporcionadas pelo programa contribuíram efetivamente para a atratividade da carreira docente e a inserção profissional do participante.

Palavras-chave: Egresso PIBID; Atratividade da carreira docente; Ingresso profissional.

\footnotetext{
1 Universidade de Taubaté, Brasil. E-mail: rafaelmarquesgobbo@gmail.com.

2 Universidade de Taubaté, Brasil. E-mail: nbambrosetti@uol.com.br.
} 